Article

\title{
Comparing Road-Kill Datasets from Hunters and Citizen Scientists in a Landscape Context
}

\author{
Florian Heigl ${ }^{1, *}$, Carina R. Stretz ${ }^{1}$, Wolfgang Steiner ${ }^{2}$, Franz Suppan ${ }^{3}$, Thomas Bauer ${ }^{3}$, \\ Gregor Laaha ${ }^{4}$ and Johann G. Zaller ${ }^{1}$ \\ 1 Institute of Zoology, University of Natural Resources and Life Sciences Vienna, Gregor Mendel Straße 33, \\ Vienna 1180, Austria; carina.stretz@students.boku.ac.at (C.R.S.); johann.zaller@boku.ac.at (J.G.Z.) \\ 2 Institute of Wildlife Biology and Game Management, University of Natural Resources and Life Sciences \\ Vienna, Gregor Mendel Straße 33, Vienna 1180, Austria; wolfgang.steiner@boku.ac.at \\ 3 Institute of Surveying, Remote Sensing and Land Information, University of Natural Resources and Life \\ Sciences Vienna, Peter-Jordan Straße 82, Vienna 1190, Austria; franz.suppan@boku.ac.at (F.S.); \\ t.bauer@boku.ac.at (T.B.) \\ 4 Institute of Applied Statistics and Computing, University of Natural Resources and Life Sciences Vienna, \\ Peter-Jordan Straße 82, Vienna 1190, Austria; gregor.laaha@boku.ac.at \\ * Correspondence: florian.heigl@boku.ac.at; Tel.: +43-1-47654-83320
}

Academic Editors: Steffen Fritz, Cidália Costa Fonte, Clement Atzberger and Prasad S. Thenkabail Received: 30 July 2016; Accepted: 28 September 2016; Published: 10 October 2016

\begin{abstract}
Road traffic has severe effects on animals, especially when road-kills are involved. In many countries, official road-kill data are provided by hunters or police; there are also road-kill observations reported by citizen scientists. The aim of the current study was to test whether road-kill reports by hunters stem from similar landscapes than those reported by citizen scientists. We analysed the surrounding landscapes of 712 road-kill reportings of European hares in the province of Lower Austria. Our data showed that road-killed hares reported both by hunters and citizens are predominantly surrounded by arable land. No difference of hedges and solitary trees could be found between the two datasets. However, significant differences in landcover classes and surrounding road networks indicate that hunters' and citizen scientists' data are different. Hunters reported hares from landscapes with significantly higher percentages of arable land, and greater lengths of secondary roads. In contrast, citizens reported hares from landscapes with significantly higher percentages of urban or industrial areas and greater lengths of motorways, primary roads, and residential roads. From this we argue that hunters tend to report data mainly from their hunting areas, whereas citizens report data during their daily routine on the way to/from work. We conclude that a citizen science approach is an important source for road-kill data when used in addition to official data with the aim of obtaining an overview of road-kill events on a landscape scale.
\end{abstract}

Keywords: citizen science; wildlife-vehicle collision; road-kill; Lepus europaeus; brown hare; public participation in science; habitat fragmentation

\section{Introduction}

Roads are omnipresent in populated regions and are an integral part of our environment that cannot be ignored when studying animals in cultural landscapes. Thus, the field of road ecology is an emerging sub-discipline within ecology [1,2]. Roads can have large and diverse effects on many animal species [3]. Although positive effects like attraction through resources and use as habitat and/or corridors for movement exist, the negative effects predominate [4]. One of the most direct negative effects of roads on animals is road-kill, along with habitat loss through roads, habitat degradation through noise, light, water, and air pollution, or movement barriers such as fences or high traffic intensities [2,5]. The frequency of road-kills is influenced by factors such as 
traffic intensity, driver awareness, roadside vegetation, time of year, or the embedment of roads in the landscape [6]. Animals especially affected by road-kill are those with a high intrinsic mobility, scavengers that use resources from roads, habitat generalists, and species that show no behavioural avoidance of open habitats [2]. Since a variety of influencing factors exist, understanding factors leading to road-kills requires data at landscape scale with a high resolution over a long time span. However, at least in Austria, the only data on road-killed animals are available for huntable wildlife-e.g., wild boar (Sus scrofa), roe deer (Capreolus capreolus), fox (Vulpes vulpes). These data are gathered by hunters, insurance companies, or police, and are generally not geo-referenced [7], which makes analyses in ecological studies nearly impossible. Some nature conservationists also collect data on road-killed amphibians, reptiles, or birds locally, but a nationwide reporting system is missing.

A very promising method of gathering ecologically relevant road-kill data is citizen science, since many potential participants drive on roads and thereby observe road-kills in their daily routine. Moreover, smartphone apps with GPS localization make it possible to provide geo-referenced road-kill data over larger areas and over longer time spans than regular (often short-termed) scientific studies [8]. Indeed, in Belgium, the Czech Republic, Ireland, South Africa, Sweden, the UK, and the United States, reporting systems for citizen observations of road-killed animals have been established [8-12]. In most projects, "presence only" data is collected, which identifies locations where road-kills occurred. "Presence only" data are challenging to analyse, but several studies show that good knowledge of the limitations of the data or the combination of opportunistic observations with other data sources produces reliable results $[8,13,14]$. A second method is targeted data collection on set transects, which provides records where wildlife are not getting killed, but this method is very cost-intensive and time consuming compared to collecting presence only data [12].

The main aim of the current study is to test if road-kill data from different sources (i.e., from hunters and citizen scientists) provide similar information on the landscapes surrounding road-kills. Therefore, we investigated whether differences between hunter and citizen data exist when testing for landscape properties (e.g., landcover, road network) associated with road-kills. We hypothesized that reports of road-killed European hare (Lepus europaeus, Pallas 1778, henceforth called "hare") from hunters and citizens differ with regard to surrounding (I) landcover; (II) landscape structure; and (III) road networks.

\section{Materials and Methods}

\subsection{Hunter and Citizen Science Datasets}

With regard to surrounding landscape, we compared data from our citizen science project with data from a comprehensive long-term cooperation project between the hunting association and the federal government of Lower Austria [15]. Hunters in this project are monitoring the roads in their hunting district regularly for road-killed game animals.

In 2013, we established a nationwide citizen science road-kill reporting system by first testing the general approach of collecting data of road-killed animals between March and June 2013 with 150 undergrad students at the University of Natural Resources and Life Sciences, Vienna [16]. Students collected data during their daily routine via EpiCollect [17] and an additional online reporting form using the university's e-learning platform based on Moodle. EpiCollect for Android and iOS allows multiple data records to be entered and stored on a mobile phone (text variables, GPS position, photo, etc.) and to be sent to a central web database. For more details on the project with the undergrad students, see [16]. In 2014, we opened the project to the public and started a media campaign to promote the project. Between January and December 2014, data collection was carried out using an online reporting form based on Wordpress [18]. In both years, the reporting form for data collection included fields such as GPS position, photo upload, species identification, and number of individuals. 
We verified the plausibility of reported road-kill data by including pictures, species description, and coordinates of the found animal. Inaccurate or untrusted data were corrected or immediately removed.

\subsection{Study Area}

After merging these two datasets, we selected the pilot area of Lower Austria due to the relatively high density of reported road-killed hares in this area (Figure 1). Lower Austria is a province in northeastern Austria, with an area of $19,186.27 \mathrm{~km}^{2}\left(47^{\circ} 25^{\prime}\right.$ to $49^{\circ} 1^{\prime} \mathrm{N} ; 14^{\circ} 27^{\prime}$ to $\left.17^{\circ} 4^{\prime} \mathrm{W}\right)$. Lower Austria consists of three different climate regions, Pannonian in the east, Alpine in the southwest, and Continental in the northwest. In the southern mountainous parts of the country and in the northwest, mixed forests are dominant. In the agricultural low-lying areas, oak-hornbeam forests are present. Beech trees characterize the forest in the west of Vienna. The topography of Lower Austria is very heterogeneous, including flat lands at $130 \mathrm{~m}$ to alpine mountains up to $2076 \mathrm{~m}$ above sea level. In Lower Austria, the length of the road network is $31,108 \mathrm{~km}$, consisting of $511 \mathrm{~km}$ of motorways and expressways, $13,598 \mathrm{~km}$ of secondary roads, and 17,000 km of municipal roads; thus, the road density is $1.62 \mathrm{~km}$ per $\mathrm{km}^{2}$. Population density of humans in the study area is 84 inhabitants per $\mathrm{km}^{2}$ [19].

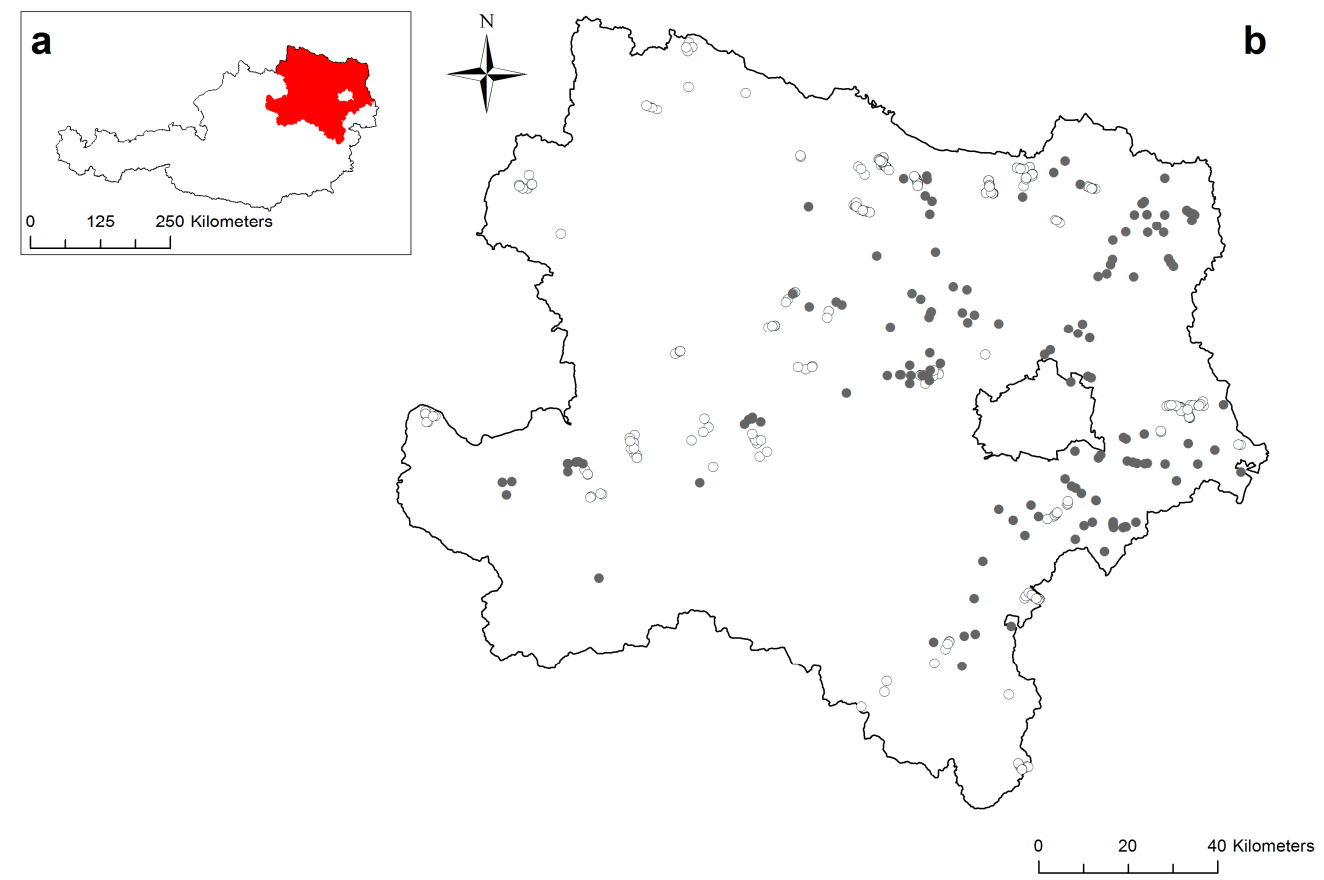

Figure 1. (a) Location of the study area $\left(19,186.27 \mathrm{~km}^{2}\right)$ in northeastern Austria; (b) Locations of reported road-killed hares by hunters (white spots) and citizens (grey spots).

\subsection{Pilot Species}

We selected the European hare as the pilot species for our data analysis. First, hares are well known by citizens, and can only be confused with mountain hare (Lepus timidus) or rabbit (Oryctolagus cuniculus), but these two species are relatively rare in the study area; second, official data from authorities on road-killed hares are collected mainly by hunters, but many hare road-kills are not reported by drivers due to little damage to the car; third, aside from hunting, road traffic seems to be one of the main causes of death in the hare in Austria $[7,20]$; fourth, the home range of the hare differs in regard to season and field size in agricultural areas, ranging from 12 ha to 300 ha, and hares can be seen in a wide geographic range. Hares primarily live in open fields and benefit from the great decline of forest cover caused by human populations [21]. They prefer field edges, which are suitable for cover and provide additional food [22,23], presumably leading to even more road-killed individuals because 
field edges are also often road edges; fifth, influencing factors on road-killed hares are not very well investigated in Austria or are not published in peer-reviewed journals, but in Germany and the Czech Republic, most accidents in adult hares occur in areas where the road is adjacent to fields or where roads are between fields and forest areas (Holisova and Obrtel 1986, Reichholf 1981, cited in [24]). Another study in Switzerland showed that hares avoid roads, so the density of roads has a negative effect on hare abundance, but the density of unpaved field tracks has a positive effect-probably due to additional food supply [25].

\subsection{Remote Sensing Data}

We used only open access data to follow the idea of open science within our citizen science approach. We used orthophotos provided by basemap.at via Web Map Tile Service (WMTS) [26], downloaded road network maps from Open Street Map (OSM) [27], and CORINE (Coordination of Information on the Environment) land cover data from Copernicus Land cover Monitoring Services [28].

At each reported road-kill hare location, we assessed the surrounding landscape within three different radii by recording the area of each landcover class. Sizes of the different radii are based on the varying reports of the home range size of hares and the minimum mapping unit (MMU) of CORINE land cover data: (a) $r=282 \mathrm{~m}$ (25 ha); (b) $r=500 \mathrm{~m}$ (78.5 ha); and (c) $r=1000 \mathrm{~m}$ (314.2 ha). CORINE land cover (CLC) is a geographic land cover/land use database for a pan-European region [29]. CLC data provides information on the biophysical characteristics of the Earth's surface based on images acquired by Earth Observation satellites with a MMU of 25 ha [29]. The CLC2012 uses a standardized European level-3 nomenclature consisting of 37 classes [30]. For reasons of clarity and comprehensibility, we used the second level of detail and here selected only classes which are present in the study area, which resulted in 11 groups (Table 1).

Table 1. Coordination of Information on the Environment (CORINE) land cover class level 2 features within the study area. CLC: CORINE land cover.

\begin{tabular}{cc}
\hline CLC Level 1 & CLC Level 2 \\
\hline Artificial surfaces & $\begin{array}{c}\text { Urban fabric } \\
\text { Industrial, commercial, and transport units } \\
\text { Mines, dumps, and construction sites } \\
\text { Artificial, non-agricultural vegetated areas }\end{array}$ \\
\hline Agricultural areas & Arable land \\
& $\begin{array}{c}\text { Permanent crops } \\
\text { Pastures }\end{array}$ \\
Forest and semi natural area & Heterogeneous agricultural areas \\
\hline Water bodies & Forests \\
\hline
\end{tabular}

To improve the information of surrounding landscapes, we additionally mapped solitary trees (number), hedge lengths (meters), and forest area (square meters) based on orthophotos published under an OpenGovernmentData (OGD) license from basemap.at within the $282 \mathrm{~m}$ radius. Additionally, we calculated the length of the road (meters) per category in the road network based on OSM within the $282 \mathrm{~m}$ radius using QGIS 2.14 for Mac [31] to test if hunters and citizens report road-kills in different surrounding road networks. We used road categorizations suited to our purpose according to feature description in OpenStreetMap Wiki: Motorway, Trunk, Primary, Secondary, Tertiary, Residential, Track, and Unclassified. Unclassified roads are minor roads and often link villages and hamlets [32]. If radii of two road-kills overlapped, we double-counted the features within. 


\subsection{Statistical Analyses}

A series of Mann-Whitney $U$ Tests [33] was performed using the "Rcmdr" package (R Commander Version 2.2-3) [34] in the open source program " $R$ " (R version 3.2.4) [35] to assess whether land cover, landscape structure, and road network length differ between road-kills reported by hunters or citizen scientists. Therefore, we performed a series of pairwise comparisons of hunter and citizen data (factor with two levels) on different dependent variables (e.g., landcover class, road category). We have chosen a non-parametric test because data on landcover classes, landscape structure, and road network length are often dominated by null-values or high percentages for single classes, and are therefore not normally distributed. As all tests are performed on different data sets, no multiple testing correction (such as the Bonferroni method) was applied.

\section{Results}

In total, 712 road-killed hares were reported in our study area of Lower Austria in 2013 and 2014. Hunters reported 567 (79.63\%) and citizens 145 hares (20.37\%; Figure 1).

\subsection{Land Cover Classes Surrounding Road-Killed Hares}

Arable land (CLC21) was the dominant land cover surrounding reported road-killed hares in both datasets (Figure 2 and Table 2). Overall, road-kill reports from hunters were surrounded by significantly more Arable Land (CLC21) than reports from citizens. Whereas citizens reported hares surrounded by significantly more Urban fabric (CLC11), Industrial, Commercial, and Transport Units (CLC12), Heterogeneous Agricultural Areas (CLC24), and in very small percentages Artificial Non-Agricultural Vegetated Areas (CLC14) and Scrubs and/or Herbaceous Vegetation (CLC32) than hunters. Differences between hunter- and citizen-reported hares regarding Forests (CLC31) and Inland Waters (CLC51) were only significant in the $1000 \mathrm{~m}$ radius. Percentage of Forests increased from the smallest to the largest radius. There was no significant difference between reported hares of hunters and citizens regarding the land cover classes of Mines, Dumps, Construction sites (CLC13), Permanent Crops (CLC22), and Pastures (CLC23).

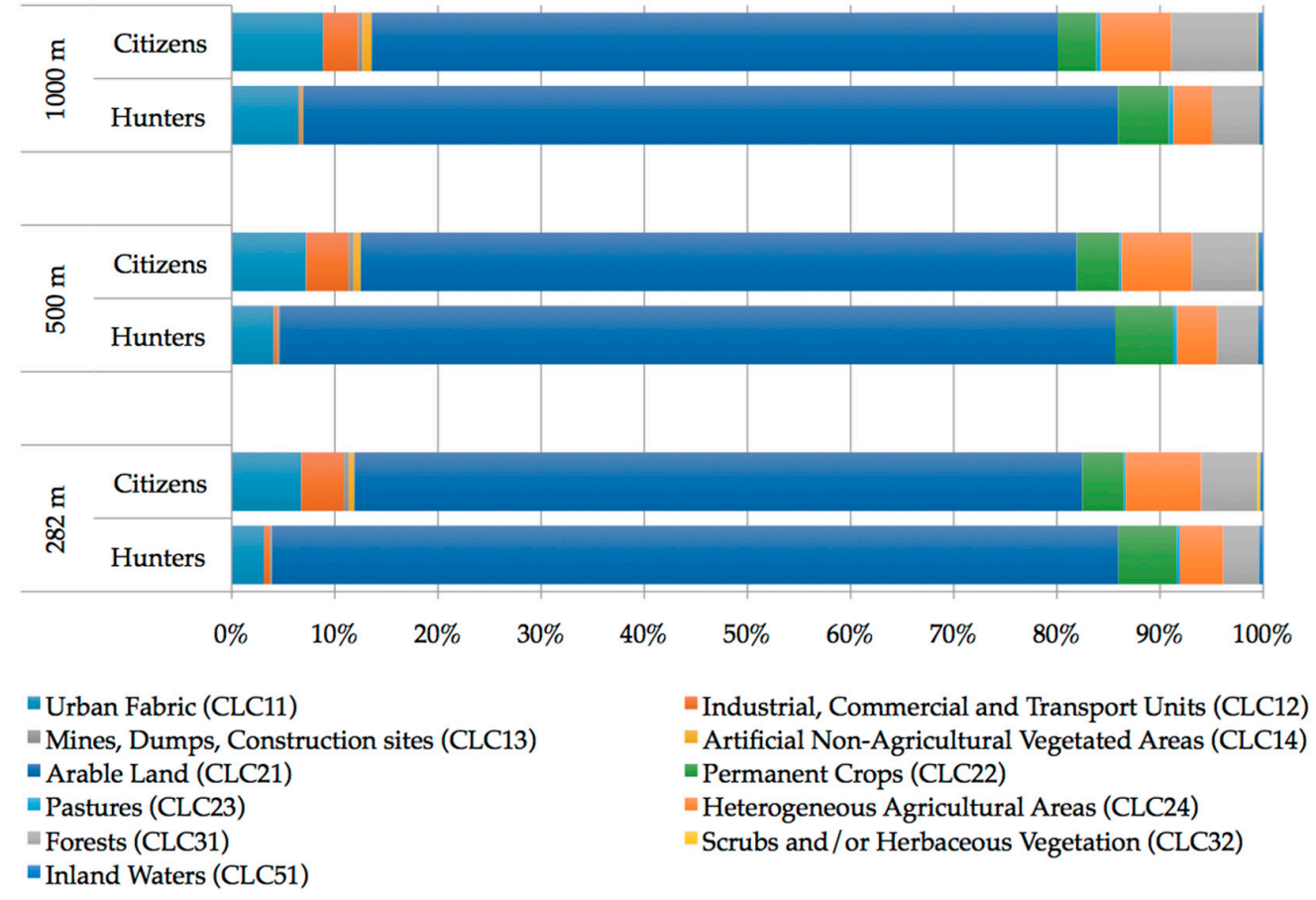

Figure 2. CORINE land cover classes in percent radii ${ }^{-1}$ in three different radii of reported road-killed hares by hunters $(n=567)$ and citizens $(n=145)$. Values are means per land cover class. 
Table 2. Proportion of CORINE land cover classes surrounding reported road-killed hares by hunters $(n=567)$ and citizens $(n=145)$ in three different radii. Means \pm SE. $p$-values from Mann-Whitney $U$ Tests (Bolded values are significant at $p=0.05$ ).

\begin{tabular}{|c|c|c|c|c|}
\hline Radius & CLC Land Cover Class & Hunters & Citizens & $p$ \\
\hline \multirow{11}{*}{$r=1000 \mathrm{~m}$} & Urban Fabric (CLC11) & $6.48 \pm 0.33$ & $8.86 \pm 0.76$ & 0.011 \\
\hline & Industrial, Commercial, and Transport Units (CLC12) & $0.19 \pm 0.06$ & $3.39 \pm 0.80$ & $<0.001$ \\
\hline & Mines, Dumps, and Construction sites (CLC13) & $0.16 \pm 0.06$ & $0.44 \pm 0.26$ & 0.420 \\
\hline & Artificial Non-Agricultural Vegetated Areas (CLC14) & $0.11 \pm 0.05$ & $0.87 \pm 0.31$ & $<0.001$ \\
\hline & Arable Land (CLC21) & $78.97 \pm 0.96$ & $66.51 \pm 2.32$ & $<0.001$ \\
\hline & Permanent Crops (CLC22) & $4.95 \pm 0.62$ & $3.76 \pm 0.98$ & 0.634 \\
\hline & Pastures (CLC23) & $0.46 \pm 0.14$ & $0.45 \pm 0.26$ & 0.879 \\
\hline & Heterogeneous Agricultural Areas (CLC24) & $3.73 \pm 0.35$ & $6.82 \pm 0.98$ & $<0.001$ \\
\hline & Forests (CLC31) & $4.60 \pm 0.49$ & $8.31 \pm 1.41$ & $<0.001$ \\
\hline & Scrubs and/or Herbaceous Vegetation (CLC32) & $0.00 \pm 0.00$ & $0.10 \pm 0.08$ & 0.007 \\
\hline & Inland Waters (CLC51) & $0.35 \pm 0.10$ & $0.49 \pm 0.19$ & 0.004 \\
\hline \multirow{11}{*}{$r=500 \mathrm{~m}$} & Urban Fabric (CLC11) & $4.09 \pm 0.40$ & $7.21 \pm 1.10$ & 0.009 \\
\hline & Industrial, Commercial, and Transport Units (CLC12) & $0.34 \pm 0.12$ & $4.11 \pm 1.02$ & $<0.001$ \\
\hline & Mines, Dumps, and Construction sites (CLC13) & $0.16 \pm 0.07$ & $0.51 \pm 0.36$ & 0.733 \\
\hline & Artificial Non-Agricultural Vegetated Areas (CLC14) & $0.05 \pm 0.03$ & $0.65 \pm 0.32$ & $<0.001$ \\
\hline & Arable Land (CLC21) & $81.02 \pm 1.15$ & $69.44 \pm 2.64$ & $<0.001$ \\
\hline & Permanent Crops (CLC22) & $5.60 \pm 0.77$ & $4.13 \pm 1.22$ & 0.5 \\
\hline & Pastures (CLC23) & $0.42 \pm 0.17$ & $0.22 \pm 0.16$ & 0.751 \\
\hline & Heterogeneous Agricultural Areas (CLC24) & $3.87 \pm 0.49$ & $6.83 \pm 1.28$ & $<0.001$ \\
\hline & Forests (CLC31) & $3.98 \pm 0.54$ & $6.28 \pm 1.49$ & 0.060 \\
\hline & Scrubs and/or Herbaceous Vegetation (CLC32) & $0.00 \pm 0.00$ & $0.16 \pm 0.16$ & 0.048 \\
\hline & Inland Waters (CLC51) & $0.48 \pm 0.17$ & $0.46 \pm 0.24$ & 0.220 \\
\hline \multirow{11}{*}{$r=282 \mathrm{~m}$} & Urban Fabric (CLC11) & $3.13 \pm 0.41$ & $6.75 \pm 1.40$ & $<0.001$ \\
\hline & Industrial, Commercial, and Transport Units (CLC12) & $0.58 \pm 0.21$ & $4.12 \pm 1.13$ & $<0.001$ \\
\hline & Mines, Dumps, and Construction sites (CLC13) & $0.18 \pm 0.08$ & $0.52 \pm 0.38$ & 0.735 \\
\hline & Artificial Non-Agricultural Vegetated Areas (CLC14) & $0.01 \pm 0.01$ & $0.51 \pm 0.32$ & 0.001 \\
\hline & Arable Land (CLC21) & $82.07 \pm 1.22$ & $70.57 \pm 2.88$ & $<0.001$ \\
\hline & Permanent Crops (CLC22) & $5.64 \pm 0.82$ & $4.05 \pm 1.31$ & 0.584 \\
\hline & Pastures (CLC23) & $0.32 \pm 0.16$ & $0.19 \pm 0.14$ & 0.859 \\
\hline & Heterogeneous Agricultural Areas (CLC24) & $4.22 \pm 0.60$ & $7.30 \pm 1.51$ & $<0.001$ \\
\hline & Forests (CLC31) & $3.48 \pm 0.56$ & $5.45 \pm 1.51$ & 0.361 \\
\hline & Scrubs and/or Herbaceous Vegetation (CLC32) & $0.00 \pm 0.00$ & $0.28 \pm 0.28$ & 0.048 \\
\hline & Inland Waters (CLC51) & $0.38 \pm 0.15$ & $0.29 \pm 0.15$ & 0.271 \\
\hline
\end{tabular}

Amount of structural elements (solitary trees, hedges, and forests) manually mapped within the $282 \mathrm{~m}$ radius showed no significant differences between hunter- and citizen-reported road-killed hares (Table 3).

Table 3. Structural landscape elements within the $282 \mathrm{~m}$ radius around road-killed hares reported by hunters $(n=567)$ and citizens $(n=145)$. Means \pm SE. $p$-values from Mann-Whitney $U$ Tests.

\begin{tabular}{ccccc}
\hline Structural Landscape Elements & Hunters & Citizens & $\chi^{\mathbf{2}}$ & $\boldsymbol{p}$ \\
\hline Forests (in ha) & $1.96 \pm 0.19$ & $2.36 \pm 0.40$ & 1.06 & 0.303 \\
Hedges (in m) & $338.33 \pm 17.35$ & $302.38 \pm 32.32$ & 0.26 & 0.613 \\
Solitary trees (No.) & $7.97 \pm 0.30$ & $7.26 \pm 0.62$ & 2.93 & 0.087 \\
\hline
\end{tabular}

\subsection{Road Network}

Overall, tracks and secondary roads dominated the surrounding landscape in the $282 \mathrm{~m}$ radius of reported hares by hunters, whereas tracks and primary roads were more dominant in road networks surrounding reported hares by citizens (Figure 3 and Table 4). Hunters reported hares with significantly greater length of secondary roads in the road network than citizens, whereas citizens reported hares in road networks with significantly greater length of motorway, primary, residential, and unclassified roads. 


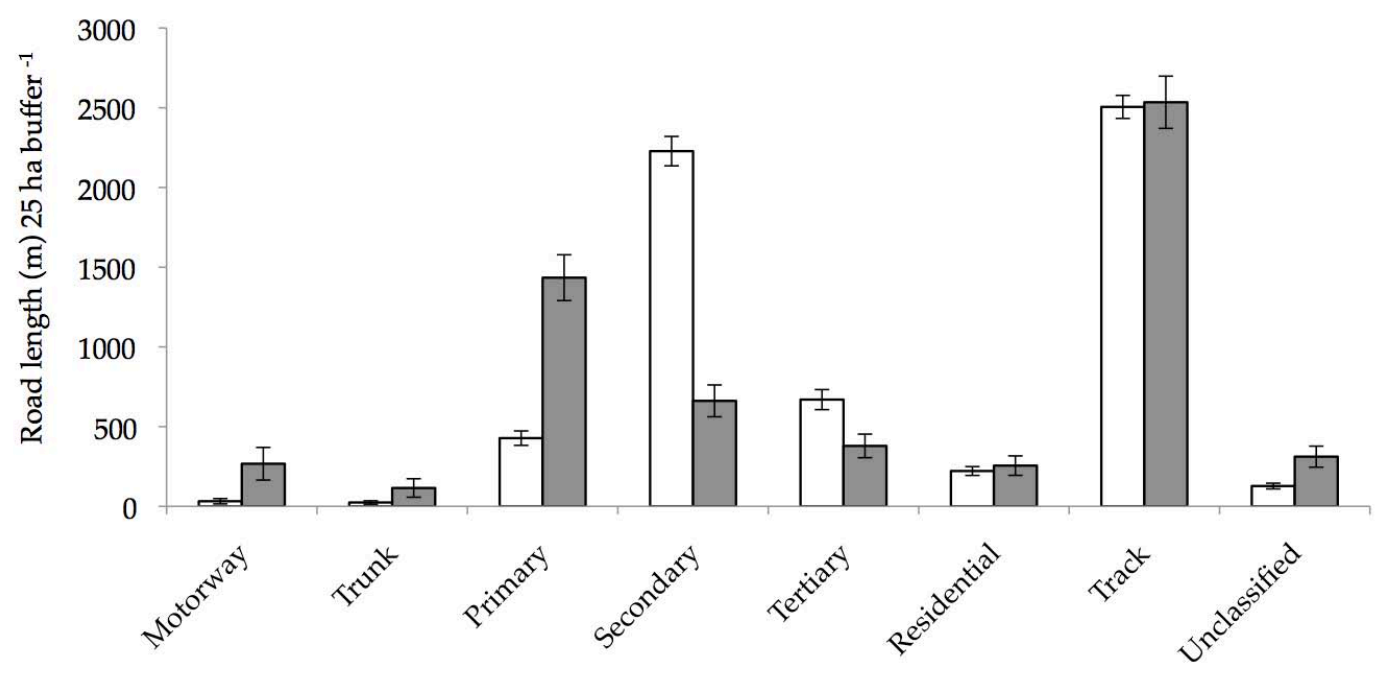

Figure 3. Lengths of road features $(\mathrm{m})$ within the $282 \mathrm{~m}$ radius of road-killed hares. Data reported by hunters are white-coloured $(n=567)$, data reported by citizens are grey-coloured $(n=145)$. Means \pm SE.

Table 4. Lengths of road features $(\mathrm{m})$ within the $282 \mathrm{~m}$ radius of road-killed hares. Means $\pm \mathrm{SE}$, hunters $n=567$, citizens $n=145$. $p$-values from Mann-Whitney $U$ Tests (Bolded values are significant at $p=0.05)$.

\begin{tabular}{cccc}
\hline & Hunters & Citizens & $\boldsymbol{p}$ \\
\hline Motorway & $32.10 \pm 16.79$ & $267.31 \pm 102.46$ & $<\mathbf{0 . 0 0 1}$ \\
Trunk & $24.30 \pm 10.70$ & $115.18 \pm 57.96$ & 0.115 \\
Primary & $427.83 \pm 45.17$ & $1434.33 \pm 143.68$ & $<\mathbf{0 . 0 0 1}$ \\
Secondary & $2227.95 \pm 92.21$ & $661.77 \pm 99.86$ & $<\mathbf{0 . 0 0 1}$ \\
Tertiary & $669.64 \pm 62.87$ & $379.16 \pm 73.91$ & 0.775 \\
Residential & $221.73 \pm 27.65$ & $255.54 \pm 60.92$ & $\mathbf{0 . 0 1 1}$ \\
Track & $2505.42 \pm 72.26$ & $2534.56 \pm 163.82$ & 0.71 \\
Unclassified & $127.50 \pm 17.87$ & $311.69 \pm 66.05$ & $<\mathbf{0 . 0 0 1}$ \\
\hline
\end{tabular}

\section{Discussion}

Road-killed hares are reported within both datasets in environments with high amounts of arable land, but with differences in the percentages of rural and artificial areas, and these differences can only be seen when analysing data from both hunters and citizens. Since hunters reported hares surrounded by significantly higher percentages of Arable Land, it fits that hares reported by hunters have greater lengths of secondary roads in the surrounding road network, which are characteristic of rural areas. However, citizens reported hares surrounded by significantly higher percentages of urban fabric or industrial areas and greater lengths of motorways, primary roads, and residential roads in the surrounding road network. From this, one can infer that hunters report data from their hunting areas, whereas citizens report data during their daily routine on the way to/from work and in their daily environment. Therefore, we conclude that data from hunters and citizen science data are complementary in our study.

\subsection{Land Cover Data}

Our results showed that reported hares were killed in various landscapes with high amounts of arable land, which is in accordance with others [21], who report that the hare is a highly adaptable species that can persist in any number of habitat types. Even though arable land and habitat diversity is positively associated with hare abundance [36,37] and hares tend to avoid the proximity of roads [25], in our study, hares were reported in a variety of land cover classes. One possible explanation for the high percentage of arable land in the surroundings of reported road-killed hares is that while hares 
generally select weeds and wild grasses for forage, intensified agro-practices have reduced this food source, resulting in selection for crop species [38].

The main aim of our study was to test whether citizen science can give the same information as reportings from hunters on road-kills over a certain geographic area. We found that the two datasets from hunters and citizen scientists showed a similar general picture with regard to the surrounding landscape. Arable land was dominant in the surrounding landscape of road-killed hares reported by hunters as well as by citizens. However, besides the dominating effect of arable land, significant differences in the percentage of different land cover classes between the two groups show that the two groups collect data in slightly different environments. Our analyses showed, that citizen scientists tended to report data of road-kills near developed areas, confirming others [9] and correlating with human population density as a key factor for spatial variation in citizen science data [39]. We conclude that this result should be considered when establishing a citizen science project with geo-referenced data or when analysing and interpreting geo-referenced citizen science data.

It also has to be noted that CORINE land cover uses a quite large MMU of 25 ha for areal phenomena data. However, since the home range of hare varies from 12-300 ha in different studies, hares can travel a long way to feeding grounds [21], and since our results are in line with previous studies, we conclude that CLC is suitable for analysing land cover surrounding road-killed European hares over large geographic areas. Additionally, analysing surrounding landscapes of road-killed hares in a study area of almost $20,000 \mathrm{~km}^{2}$ would be impossible without CORINE data, and it is the most detailed open access data on land cover available. Indeed, other citizen science studies used CLC in combination with different species ranging from insects to birds [40-43]. Another promising dataset based on citizen science would be land cover classification in OpenStreetMap, but unfortunately only $27 \%$ of Austria is mapped until summer 2016 [44].

Our results based on manually mapping forests, hedges, and solitary trees showed no significant differences. We recommend using remote sensing in combination with, for example, conventional habitat classification via plant species mapping on local scales to look for influences of surrounding land cover on high-resolution.

\subsection{Consequences of the Citizen Science Road-Kill Reporting System}

The comparison of hunter and citizen data on road-killed hares in our pilot area indicates that we have to include the social or demographic background of our participants in our road-kill reporting system. Since our results show that different groups report slightly different data on the same research object, merging the background and motivations of project participants with ecological data could lead to a better understanding of road-kill patterns based on citizen science projects. Others [45] have shown that effort data are especially important when analysing citizen science data on a landscape scale, because without effort data, it is difficult in species monitoring to distinguish between bias in sampling effort and species occurrence. Implementing effort data in data mining models and similar techniques can be helpful to reduce observer bias in large-scale ecological data [46,47]. Our findings suggest that citizen science is suitable for monitoring animal road-kills, and consequently support previous studies $[8,14,48]$. Official reportings of road-kills are indispensable, because they cover different regions than citizen scientists. However, these official data are often not geo-referenced, making citizen science data more suitable for the analysis of ecological interactions between surrounding landscape structure and road-kills on a large scale. One key advantage of citizen science road-kill projects is that roads are easily accessible to the public, thus avoiding spatial bias in citizen science projects beforehand [39]. Using citizen science produces other challenges in road-kill monitoring, such as building a social network, preparing educational materials, designing and maintaining adequate reporting systems, and rigid data verification [12]. Some recommendations of how to set up a citizen science road-kill observation system are continuous inclusion of broad participant types, use of standardized data collection methods, or establishing extensive social networks [12]. 
We are currently collecting data on a large scale with apps for smartphones and a new designed project website (www.roadkill.at/en) using a simplified reporting form. Our future challenges will be to implement some of the recommendations discussed above and add the option of a targeted monitoring with hypotheses testing [49]. Additionally, we strive to standardize road-kill data collection in Austria and convince professionals (e.g., hunters and road administrators) to use one geo-referenced reporting system.

As citizen science is critically viewed in the scientific community due to possible biases in data collection $[49,50]$, it is important to demonstrate that it seems very promising in the collection of robust road-kill data $[14,48]$. Furthermore, citizen science data can raise public awareness on accident risks and related biodiversity concerns, but it should be used as complement to official reports rather than as a replacement [51].

\section{Conclusions}

In our study, significant differences in landcover classes and surrounding road networks indicate that hunters' and citizen science data are indeed different. We conclude that different data sources can influence the results of road-kill studies. This is especially important for citizen science projects in which participants with very diverse backgrounds report data. Additionally, thinking of nationwide road-kill reporting systems with different data sources, we recommend the inclusion of the social or demographic background of reporters. Further research is needed on what factors affect data quality in citizen science road-kill projects, and particularly how different participants influence datasets.

Acknowledgments: We wish to thank all citizen scientists in Project Roadkill for investing time and reporting data. Comments of four anonymous reviewers helped to improve former versions of this manuscript. We want to thank Benjamin Dauth for his huge support, Julia Freinschlag for the design of the Logo, Horst Hellmeier for the illustrations and Tassilo Posegga who developed the first website. Alexander Bruckner supported the development of the first online platform as head of the Institute of Zoology at the University of Natural Resources and Life Sciences Vienna. This work was partly funded by the University of Natural Resources and Life Sciences Vienna, Citizen Science Network. The project "Wild und Verkehr Niederösterreich" was funded by Landesjagdverband Niederösterreich and the federal state of Lower Austria.

Author Contributions: Florian Heigl and Johann G. Zaller conceived and designed the study; Florian Heigl, Johann G. Zaller, Carina R. Stretz and Wolfgang Steiner performed the study; Florian Heigl, Thomas Bauer, Franz Suppan and Gregor Laaha analysed the data; Florian Heigl, Johann G. Zaller, Gregor Laaha and Wolfgang Steiner wrote the paper.

Conflicts of Interest: The authors declare no conflict of interest.

\section{Abbreviations}

The following abbreviations are used in this manuscript:

$\begin{array}{ll}\text { CLC } & \text { CORINE Land Cover Class } \\ \text { CORINE } & \text { Coordination of Information on the Environment } \\ \text { MMU } & \text { Minimum Mapping Unit } \\ \text { OGD } & \text { Open Government Data } \\ \text { OSM } & \text { OpenStreetMap } \\ \text { WMTS } & \text { Web Map Tile Service }\end{array}$

\section{References}

1. Van der Ree, R.; Smith, D.J.; Grilo, C. Handbook of Road Ecology; John Wiley \& Sons: West Sussex, UK, 2015.

2. Forman, R.T.T.; Sperling, D.; Bissonette, J.A. Road Ecology: Science and Solutions; Island Press: Washington, DC, USA, 2003.

3. Trombulak, S.C.; Frissell, C.A. Review of ecological effects of roads on terrestrial and aquatic communities. Conserv. Biol. 2000, 14, 18-30. [CrossRef]

4. Fahrig, L.; Rytwinski, T. Effects of roads on animal abundance: An empirical review and synthesis. Ecol. Soc. 2009, 14, 21.

5. Van der Ree, R.; Smith, D.J.; Grilo, C. The ecological effects of linear infrastructure and traffic: Changes and oppurtunities of rapid global growth. In Handbook of Road Ecology; John Wiley \& Sons: West Sussex, UK, 2015. 
6. Seiler, A. Ecological Effects of Roads-A Review; Swedish University of Agricultural Sciences: Uppsala, Sweden, 2001.

7. Neumann, F. Fallwild 2014/15: Haarwild (Hasen, Wildkaninchen, Murmeltiere, Dachse) nach Bundesländern; Bundesanstalt Statistik Österreich: Wien, Austria, 2015.

8. Vercayie, D.; Herremans, M. Citizen science and smartphones take roadkill monitoring to the next level. Nat. Conserv. 2015, 11, 29-40. [CrossRef]

9. Shilling, F.M.; Waetjen, D.P. Wildlife-vehicle collision hotspots at US highway extents: Scale and data source effects. Nat. Conserv. 2015, 11, 41-60. [CrossRef]

10. Shilling, F.M. Programs / Global Roadkill Network. Available online: http://globalroadkill.net/ (accessed on 9 January 2016).

11. Lee, T.; Quinn, M.S.; Duke, D. Citizen, science, highways, and wildlife: Using a web-based GIS to engage citizens in collecting wildlife information. Ecol. Soc. 2006, 11, 11.

12. Shilling, F.M.; Perkins, S.E.; Collinson, W. Wildlife/Roadkill Observation and Reporting Systems. In Handbook of Road Ecology; John Wiley \& Sons: West Sussex, UK, 2015.

13. Snäll, T.; Kindvall, O.; Nilsson, J.; Pärt, T. Evaluating citizen-based presence data for bird monitoring. Biol. Conserv. 2011, 144, 804-810. [CrossRef]

14. Paul, K.; Quinn, M.S.; Huijser, M.P.; Graham, J.; Broberg, L. An evaluation of a citizen science data collection program for recording wildlife observations along a highway. J. Environ. Manag. 2014, 139, 180-187. [CrossRef] [PubMed]

15. Steiner, W. Projekt Wild und Verkehr Niederösterreich. Available online: https://forschung.boku.ac.at/fis/ suchen.projekt_uebersicht?sprache_in=de\&menue_id_in=300\&id_in=9609 (accessed on 11 July 2016).

16. Heigl, F.; Zaller, J.G. Using a citizen science approach in higher education: A case study reporting roadkills in Austria. Hum. Comput. 2014, 1. [CrossRef]

17. Aanensen, D.M.; Huntley, D.M.; Feil, E.J.; al-Own, F.; Spratt, B.G. EpiCollect: Linking smartphones to web applications for epidemiology, ecology and community data collection. PLoS ONE 2009, 4. [CrossRef] [PubMed]

18. Matt, M.; Helen, H.S.; Dion, H.; Mark, J.; Andrew, N.; Andrew, O. The Wordpress Project. Available online: https:// wordpress.org/ (accessed on 30 September 2016).

19. Herry, M.; Sedlacek, N.; Steinacher, I. Transport in Figures-Austria Edition 2011; Federal Ministry for Transport, Innovation and Technology (bmvit): Vienna, Austria, 2012.

20. Haerer, G.; Nicolet, J.; Bacciarini, L.; Gottstein, B.; Giacometti, M. Causes of death, zoonoses, and reproduction in the European brown hare in Switzerland. Schweiz. Arch. Tierheilkd. 2001, 143, 193-201. [PubMed]

21. Flux, J.E.C.; Angermann, R. Chapter 4: The Hares and Jackrabbits. In Rabbits, Hares and Pikas: Status Survey and Conservation Action Plan; The World Conservation Union: Gland, Switzerland, 1990; pp. 61-94.

22. Schai-Braun, S.C.; Hacklaender, K. Home range use by the European hare (Lepus europaeus) in a structurally diverse agricultural landscape analysed at a fine temporal scale. Acta Theriol. 2014, 59, 277-287. [CrossRef]

23. Cardarelli, E.; Meriggi, A.; Brangi, A.; Vidus-Rosin, A. Effects of arboriculture stands on European hare Lepus europaeus spring habitat use in an agricultural area of northern Italy. Acta Theriol. 2010, 56, 229-238. [CrossRef]

24. Glitzner, I.; Beyerlein, P.; Brugger, C.; Paill, W.; Schlögel, B.; Tataruch, F. Literaturstudie zu anlage- und betriebsbedingten Auswirkungen von Straßen auf die Tierwelt. Endbericht.; Magistratsabteilung 22-Umweltschutz, Magistrat der Stadt Wien: Wien, Austria, 1999; p. 176.

25. Roedenbeck, I.A.; Voser, P. Effects of roads on spatial distribution, abundance and mortality of brown hare (Lepus europaeus) in Switzerland. Eur. J. Wildl. Res. 2008, 54, 425-437. [CrossRef]

26. Basemap.at-Verwaltungsgrundkarte Österreichs. Available online: https://www.basemap.at/ (accessed on 5 July 2016).

27. Open Street Map. Available online: https://www.openstreetmap.org/ (accessed on 5 July 2016).

28. CLC 2012-Copernicus Land Monitoring Services. Available online: http://land.copernicus.eu/paneuropean/corine-land-cover/clc-2012 (accessed on 5 July 2016).

29. Copernicus Programme. Pan-European Component: CORINE Land Cover; Copernicus Land Service: Geneva, Switzerland, 2015.

30. CLC Classes. Available online: http://uls.eionet.europa.eu/CLC2000/classes/index_html (accessed on 12 July 2016). 
31. QGIS Development Team. QGIS Geographic Information System. Available online: http://qgis.osgeo.org (accessed on 8 October 2016).

32. Map Features-OpenStreetMap Wiki. Available online: http://wiki.openstreetmap.org/wiki/Map_Features (accessed on 12 July 2016).

33. Mann, H.B.; Whitney, D.R. On a Test of Whether one of Two Random Variables is Stochastically Larger than the Other. Ann. Math. Stat. 1947, 18, 50-60. [CrossRef]

34. Fox, J. The R commander: A basic statistics graphical user interface to R. J. Stat. Softw. 2005, 14, 1-42. [CrossRef]

35. R Development Core Team. R: A Language and Environment for Statistical Computing; R Foundation for Statistical Computing: Vienna, Austria, 2008.

36. Smith, R.K.; Vaughan Jennings, N.; Harris, S. A quantitative analysis of the abundance and demography of European hares Lepus europaeus in relation to habitat type, intensity of agriculture and climate. Mammal Rev. 2005, 35, 1-24. [CrossRef]

37. Vaughan, N.; Lucas, E.A.; Harris, S.; White, P.C.L. Habitat associations of European hares Lepus europaeus in England and Wales: Implications for farmland management. J. Appl. Ecol. 2003, 40, 163-175. [CrossRef]

38. Reichlin, T.; Klansek, E.; Hackländer, K. Diet selection by hares (Lepus europaeus) in arable land and its implications for habitat management. Eur. J. Wildl. Res. 2006, 52, 109-118. [CrossRef]

39. Mair, L.; Ruete, A. Explaining Spatial Variation in the Recording Effort of Citizen Science Data across Multiple Taxa. PLoS ONE 2016, 11. [CrossRef] [PubMed]

40. Clavel, J.; Julliard, R.; Devictor, V. Worldwide decline of specialist species: Toward a global functional homogenization? Front. Ecol. Environ. 2011, 9, 222-228. [CrossRef]

41. Deguines, N.; Julliard, R.; de Flores, M.; Fontaine, C. The whereabouts of flower visitors: Contrasting land-use preferences revealed by a country-wide survey based on citizen science. PLoS ONE 2012, 7. [CrossRef] [PubMed]

42. Muratet, A.; Fontaine, B. Contrasting impacts of pesticides on butterflies and bumblebees in private gardens in France. Biol. Conserv. 2015, 182, 148-154. [CrossRef]

43. Le Rest, K.; Pinaud, D.; Bretagnolle, V. Volunteer-based surveys offer enhanced opportunities for biodiversity monitoring across broad spatial extent. Ecol. Inform. 2015, 30, 313-317. [CrossRef]

44. Arsanjani, J.J.; Vaz, E.; Bakillah, M.; Mooney, P. Towards Initiating OpenLandMap Founded on Citizens' Science: The Current Status of Land Use Features of OpenStreetMap in Europe. Available online: http:/ / repositori.uji.es/xmlui/handle/10234/98805 (accessed on 8 October 2016).

45. Zuckerberg, B.; McGarigal, K. Widening the Circle of Investigation-The interface between Citizen Science and Landscape Ecology. In Citizen Science: Public Participation in Environmental Research; Cornell University Press: Ithaca, NY, USA, 2012.

46. Fink, D.; Hochachka, W.M. Using data mining to discover biological patterns in citizen science observations. In Citizen Science: Public Participation in Environmental Research; Cornell University Press: Ithaca, NY, USA, 2012; pp. 125-138.

47. Lakeman-Fraser, P.; Gosling, L.; Moffat, A.J.; West, S.E.; Fradera, R.; Davies, L.; Ayamba, M.A.; van der Wal, R. To have your citizen science cake and eat it? Delivering research and outreach through Open Air Laboratories (OPAL). BMC Ecol. 2016, 16, 57-70. [CrossRef] [PubMed]

48. Olson, D.D.; Bissonette, J.A.; Cramer, P.C.; Green, A.D.; Davis, S.T.; Jackson, P.J.; Coster, D.C. Monitoring wildlife-vehicle collisions in the information age: How Smartphones can improve data collection. PLoS ONE 2014, 9. [CrossRef] [PubMed]

49. Dickinson, J.L.; Zuckerberg, B.; Bonter, D.N. Citizen science as an ecological research tool: Challenges and benefits. Annu. Rev. Ecol. Evol. Syst. 2010, 41, 149-172. [CrossRef]

50. Lewandowski, E.; Specht, H. Influence of volunteer and project characteristics on data quality of biological surveys. Conserv. Biol. 2015, 9, 713-723. [CrossRef] [PubMed]

51. Seiler, A.; Helldin, J.O. Greener transport infrastructure-IENE 2014 International Conference. Nat. Conserv. 2015, 11, 5-12. [CrossRef]

(C) 2016 by the authors; licensee MDPI, Basel, Switzerland. This article is an open access article distributed under the terms and conditions of the Creative Commons Attribution (CC-BY) license (http://creativecommons.org/licenses/by/4.0/). 